Mieczysław Gajos

Uniwersytet Łódzki

\title{
Katarzyna Karpińska-Szaj NAUCZANIE JĘZYKÓW OBCYCH UCZNIÓW Z NIEPELNOSPRAWNOŚCIĄ W SZKOŁACH OGÓLNODOSTĘPNYCH
}

POZNAŃ: WYDAWNICTWO UNIWERSYTETU IM. ADAMA MICKIEWICZA, 2013, STR. 240.

Najnowsza monografia Katarzyny Karpińskiej-Szaj Nauczanie języków obcych uczniów z niepełnosprawnościq w szkołach ogólnodostępnych dotyczy istotnych naukowo-społecznych kwestii związanych z niepełnosprawnością ucznia w kontekście glottodydaktycznym. Problematyka tytułowa monografii nie była przedmiotem wcześniejszych kompleksowych opracowań ani ze strony pedagogów, ani ze strony glottodydaktyków czy językoznawców. Tym samym, publikacja Katarzyny Karpińskiej-Szaj stanowi całościowe, całkiem nowe i oryginalne spojrzenie na zagadnienia dotyczące procesu przyswajania języków obcych (JO) przez uczniów z określonymi, zdiagnozowanymi deficytami zdrowotnymi.

Książka Nauczanie języków obcych uczniów z niepełnosprawnościq w szkołach ogólnodostępnych wychodzi naprzeciw zmianom, które zachodzą w polskim systemie oświatowym w zakresie kształcenia uczniów ze specjalnymi potrzebami. Dostrzeżenie tych potrzeb przez władze resortu edukacji i podejmowanie działań na rzecz dostosowywania się placówek oświatowych ogólnodostępnych dla potrzeb uczniów z niepełnosprawnością, proponowanie nowych programów kształcenia, poszukiwanie optymalnych form pracy z uczniami, czy też opracowanie zaleceń w zakresie dostosowywania szeroko rozumianej organizacji życia w szkole do różnorodnych potrzeb uczniów, także tych tzw. „specjalnych" jest ważnym sygnałem umożliwiającym realne wdrożenie idei integracji w polskim systemie edukacyjnym na różnych szczeblach kształcenia. 
Integracja, o której mowa niesie za sobą konieczność nowego spojrzenia na klasę jako środowisko uczniowskie, w którym mogą przebywać uczniowie o różnym stopniu niepełnosprawności, różnych potrzebach, ale także różnych możliwościach ich zaspakajania czy realizacji. Stąd całkiem oczywiste wydaje się postulowanie indywidualizacji procesu dydaktycznego w grupach, w których znajdują się dzieci z niepełnosprawnością.

W kontekście realizowanego w systemie klasowym procesu nauczania/uczenia się języków obcych, niezbędne wydaje się odpowiednie przygotowanie nauczycieli JO, które pozwoli im na zdobycie dodatkowej wiedzy, określonych umiejętności, tak aby sprostać wyzwaniom jakie stawia przed pedagogiem obecność w szkole ogólnodostępnej ucznia/uczniów z różnorodnymi deficytami zdrowotnymi.

Ponieważ opracowanie Katarzyny Karpińskiej-Szaj wnosi wiele istotnych treści w omawiane zagadnienie z punktu widzenia glottodydaktycznego, dostarczając czytelnikowi ciekawych i oryginalnych wniosków mających niepodważalną wartość teoretyczną i praktyczną, recenzowana książka powinna zainteresować szerokie grono odbiorców od studentów neofilologii po czynnych nauczycieli języków obcych, osoby odpowiedzialne za kształcenie i doskonalenie zawodowe nauczycieli JO, a także decydentów mających wpływ na organizację procesu kształcenia w polskiej szkole. Uważam, że lektura książki mogłaby być również pomocna dla rodziców, chcących lepiej zrozumieć uwarunkowania i konsekwencje płynące z proponowanych rozwiązań integracyjnych.

Monografia Nauczanie języków obcych uczniów z niepełnosprawnościq w szkołach ogólnodostępnych została podzielona na cztery rozdziały:

1. Integracja uczniów z niepełnosprawnością w szkołach ogólnodostępnych.

2. Edukacja językowa w szkolnej integracji indywidualnej.

3. Nauczanie języków obcych, a działania terapeutyczne.

4. Skuteczność nauczania języków obcych uczniów z niepełnosprawnością. Autorka omawia w nich kolejno argumenty przemawiające za integracją uczniów z niepełnosprawnością w szkołach ogólnodostępnych, charakteryzuje wyzwania jakie przed szkołą stawia obecność ucznia/uczniów ze specjalnymi potrzebami, ale także dostrzega pewne ograniczenia i utrudnienia jakie może napotykać idea integracji edukacyjnej w polskim systemie oświaty. Dlatego też za w pełni uzasadnione i cenne należy uznać przytoczenie przez Katarzynę Karpińską-Szaj w pierwszym rozdziale swojej książki prac ustawodawczych regulujących organizację kształcenia integracyjnego, dostosowywania szkół i realizowanych w nich programów do rzeczywistych potrzeb uczniów, sprzyjających wyrównywaniu szans edukacyjnych dzieci i młodzieży z niepełnosprawnością. 
Po zarysowaniu sytuacji uczniów z niepełnosprawnością w kontekście organizacji procesu dydaktyczno-wychowawczego w polskim systemie oświatowym oraz wdrażanych systemowo uregulowań prawnych, Autorka skupia swoją uwagę w rozdziałach od drugiego do czwartego na zagadnieniach dotyczących procesu glottodydaktycznego uczniów z niepełnosprawnością. Ze znawstwem przedmiotu, bazując na wieloletnich swoich wcześniejszych badaniach oraz doświadczeniach przybliża czytelnikowi istotne zagadnienia dotyczące organizacji procesu nauczania/uczenia się języka w zintegrowanych zespołach uczniowskich: definiuje cele nauczania JO uczniów z niepełnosprawnością, omawia zasady indywidualizacji, wskazując przy tym na konieczność zintegrowanego podejścia do procesu nauczania/uczenia się języków obcych dzieci i młodzieży ze specjalnymi potrzebami edukacyjnymi. Pisząc o konieczności rozwijania kompetencji językowych uczniów, Autorka podkreśla płynące z faktu uczenia się języka przez dzieci z niepełnosprawnością inne, dodatkowe, wymierne korzyści o charakterze poznawczo-emocjonalnym, które towarzyszą właściwie zorganizowanemu procesowi glottodydaktycznemu.

Za szczególnie cenny uważam rozdział III omawianej monografii, w którym Autorka w sposób bardzo przejrzysty i przekonywujący omawia korzyści terapeutyczne płynące z faktu uczenia się JO przez uczniów z niepełnosprawnością, choć jak sama zauważa: „nie w każdej sytuacji niepełnosprawności/deficytów osiągnięcie wysokich kompetencji językowo-komunikacyjnych jest możliwe". Bardzo przydatne dla nauczycieli mogą okazać się uwagi na temat typowych trudności językowych obserwowanych na poziomie poszczególnych podsystemów języka, przyswajania pojęć czy też skuteczności komunikacyjnej. Katarzyna Karpińska-Szaj, na łamach swojej monografii nie ogranicza się tylko do charakterystyk wybranych trudności językowych uczniów, ale omawia również sposoby kompensowania ich deficytów językowych, komunikacyjnych czy poznawczych poprzez właściwie zorganizowany proces nauczania/uczenia się języka obcego.

Pomimo braku wyraźnego przyrostu efektów w sferze językowokomunikacyjnej, Autorka wskazuje na inne korzyści płynące z faktu uczenia się języka obcego przez osoby z niepełnosprawnością: psychologiczne, dydaktyczne czy też terapeutyczne. Zagadnienie skuteczności nauczania języków obcych uczniów z niepełnosprawnością zostało rozwinięte i szczegółowo omówione w ostatnim rozdziale recenzowanej monografii. Odnajdziemy tutaj również cenne uwagi dotyczące ewaluacji stopnia przyswojenia sobie wiedzy i umiejętności językowych, między innymi te, które dotyczą wymagań egzaminacyjnych (mowa o tzw. egzaminach zewnętrznych) i możliwości ich dostosowywania do poszczególnych uczniów. 
Dzięki badaniom i zainteresowaniom naukowym Katarzyny Karpińskiej-Szaj, otrzymaliśmy bardzo cenną, oryginalną publikację, która wnosi wiele nowych, istotnych informacji dotyczących dydaktyki językowej uczniów z niepełnosprawnością. Poprzez swoją monografię, Autorka w sposób bardzo rzeczowy i odważny zabiera głos w debacie naukowej, która dotyczy istotnych problemów związanych ze specyfiką organizacji procesu dydaktycznego w wyjątkowym środowisku uczniowskim. Nacechowana aktualnością podnoszonych i omawianych kwestii, najnowsza książka autorstwa Katarzyny Karpińskiej-Szaj jest bardzo cenna nie tylko w wymiarze merytoryczno-metodologicznym, ale również w swojej wymowie społecznej. 